\title{
Faith, An Alien and Narrow Path of Christian Ethics in Migration
}

\author{
Johnson Kwabena Asamoah-Gyadu
}

\section{1 \\ Preamble}

This chapter deals with the sensitive issue of misrepresentations of identities relating to international migration involving West African Christians and the immigrant churches in which they worship. We focus on issues bordering on situation ethics and the inevitable tensions created between Christian morality and illegal means of survival abroad. In situation ethics theory, which is applied in a very limited way here, there is usually no predefinition of good or bad. Judgments are based on the situation. Situationists are familiar with existing rules and regulations but they refuse to be bound by any principle in absolute terms. This theory, developed in the middle of the 1960 s by Joseph Fletcher, proved quite influential at the time (Fletcher 1966). William Barclay, explaining aspects of it, notes that the situationist is always confronting people with decisions. Principles only advise but do not possess the right of veto. In situation ethics, principles for instance are abandoned, left or disregarded, if the command to love a neighbour can be better served by so doing (Barclay 1971: 69-91).

The commonest issue regarding migration to which many Africans apply the ethics of situation is when they decide to overstay their visas or enter other countries illegally. Survival in the diaspora usually requires making several false declarations. The common belief that those who have their way with the authorities are those who tell the best lies. So for example, it is not uncommon for people with legal documents to marry their own siblings on paper in order to facilitate relocation abroad. It is seen as a gesture of love for family rather than in terms of breaking the law. After all, as Barclay explains, for the situationist there is one thing and one only that is 'absolutely, always, and universally good-and that one thing is love' which is also the ultimate norm for Christian decision-making (Barclay 1971: 70). Here in this chapter, we will find a Ghanaian citizen of the Netherlands, a Christian who for example defies the law to accommodate a fellow undocumented Ghanaian member of her church in her home. We also encounter African immigrant churches openly announcing that some members who are legal have documents available for illegals who need documents to find work. The action is illegal but

Originally published in Exchange 43 (2014) 68-88.

(C) JOHNSON KWABENA ASAMOAH-GYADU, 2016 | DOI 10.1163/9789004326156_010

This is an open access chapter distributed under the terms of the CC-BY-NCLLicense, 
their undocumented brothers and sisters in Christ need to eat, be clothed and find places to stay and the documented also need the funds from these actions to supplement their income.

Many undocumented African immigrants seeking to work or regularize their status as resident aliens in the West also go to church and therefore profess to be Christian, however loosely interpreted. Some see their sojourn in the former heartlands of Christianity in terms of mission to the West, that is, as the call of God to restore the declining fortunes of the faith. To all intents and purposes therefore, being people of faith presupposes the adoption of lifestyles of truth. However, their living conditions and situations in terms of the choice to live abroad without proper documentation often means relying on misrepresentations. Many details may be falsified including age, marriage, nationality, reasons for migration, names, and other personal details to survive. On nationality for example, an illegal Ghanaian migrant could claim to be from another war-torn African country to avoid repatriation on humanitarian grounds. The most common misrepresentations include illegal aliens entering into 'contract marriages' or using the documents of others to gain employment. This practice is widespread and African churches, as we noted above, often announce that 'there are papers' available for anybody looking for legal documents to work. Those who make their documents available make a living out of it by charging fees for them.

The desire to migrate from Africa is very strong and partly heightened by impressive stories, photographs and videos of weddings and parties on the good social lives that friends and relations have abroad (Levitt 2007: 23). The overwhelming reason for migration though, has to do with economics. Most of the Africans whose situations are discussed here are recent migrants. They have mostly travelled to Europe from other African countries either directly or through some another African country closer to Europe such as Libya and Morocco. These migrations have occurred only within the last two and a half decades and this at the height of the collapse of many African economies. The collapse of economies has been due to a combination of factors such as military interventions in the processes of governance, massive corruption and the adoption of economic recovery programs that continue to have telling negative effects on the most vulnerable of the continent. Migrations from West Africa have mostly been towards Germany, Italy, Great Britain, the Netherlands, and the USA with major cities in these countries having quite sizeable proportions of West African communities.

For many of these migrants, Europe and North America have become earthly heavens and they aspire to migrate there in search of improved economic conditions. That Ghanaian remittances from abroad have since the 
1990 come to constitute the third main source of income to the country is only one evidence of the importance of migration to modern African economies. Ghanaians travel to the West to take up all sorts of menial and low-income employments and often work without the proper resident documentation and work permits. The increased numbers of West African migrants from countries such as Ghana in Europe and other Western locations has led to the drafting of new legislation in these countries aimed at arresting the situation. Thus in a paper focusing on marriage as a means of regularizing residential status in the Netherlands, Rijk van Dijk points to how the Dutch government introduced a series of laws in the late 1990s aimed at dealing with illegal immigration. One of these was the coding of citizens to be able to track certain personal details. For the purposes of this chapter, we note that certain African countries, including Ghana, were blacklisted 'for having a notorious record of producing fraudulent identity documents' (Van Dijk 2004: 453).

\section{Migrating as Divine Destiny}

Today desperate Africans avail themselves for all kinds or religious rituals that are meant to facilitate travel arrangements and help them survive in the diaspora. The countries concerned have for the last three decades become for many Africans places of 'divine destiny' and promise for material prosperity. Whether they are practicing Christians or not, the new 'promised lands' for young Africans are in the West, and there is much preaching that sustains this mind-set in Pentecostal rhetoric and enough rituals of facilitation to make sure ambitious dreams to travel abroad come true. The desire with which some cross the oceans and deserts in risky travel arrangements and how people continue to proceed in spite of the casualties, are enough to explain how desperate the situation is. Our concern would be how within Christian churches, travel arrangements are facilitated through prayer, even when it is clear that the potential migrant is doing so illegally. It is not only Christians who travel, but the thought behind this paper is that studies in Christian mission need to start reflecting on the pastoral, ethical, and moral implications of certain types of migration.

Within the theological context of Pentecostalism in Africa, I have argued in Contemporary Pentecostal Christianity, traveling abroad constitutes an important index of the workings of the prosperity theology (Asamoah-Gyadu 2013: $38 \mathrm{ff})$. In the sort of Pentecostal Christianity that preaches this gospel in West Africa, international travel provides access to those material things and opportunities that indicate that a person is blessed by God. Thus in migration experiences, we are dealing not simply with unemployed African youth struggling 
for survival but many others who have come to believe that the opportunities offered by migration are part of God's purposes for their lives. Thus there are many graduates and young professionals who also, driven by dreams of prosperity, travel abroad often leaving lucrative jobs and business for less dignifying Western options. What matters for them at the end of the day is not so much what work they do, but the material acquisitions that testify of God's faithfulness.

The moral issues associated with migration often begin at the point of application for the visa. People pray in churches to God for visitor's visas knowing that once these are received, they are not returning to Africa. In most cases therefore, the illegal alien populations would be made up both of people who used unapproved reasons to enter Western countries, those who overstayed their short-term visas and students who refuse to return home to Africa on completion of courses.

\section{3}

\section{Diaspora Religion and Morality}

The unprecedented upsurge in the numbers of African immigrants traveling to settle in Europe and North America, Afe Adogame has argued, 'heralds a new phase in the history of African diaspora' (Adogame 2013: viii). The expression 'diaspora' is adopted here in loose reference to African Christians living anywhere in the developed world in search of better living conditions. We argue that religion, especially Christianity and increasingly certain forms of Pentecostalism, plays an important role in the process of migration and survival in the diaspora. They do so unmindful of the false representations that migrants make in order to continue to live abroad permanently. Many Africans who undergo complex forms of immigration processes, Adogame points out, have carried with them their religio-cultural identities. Religion in Africa, especially the revivalistic or Pentecostal type tends to be deployed as a survival strategy and so the sojourn in new and precarious geo-political contexts leads to situations that encourage 'immigrants to identify, organize, and reconstruct their religion both for themselves and their host societies' (Adogame 2013: viii).

Magda is Ghanaian and a single mother of two living in New York. Within six months of encountering the Ghanaian father of her twin girls, she had resigned her job as a banker and relocated to the UsA to marry. On arrival, a wedding was celebrated in a Ghanaian Pentecostal church; the leadership knew that both were undocumented. Preparations to travel had been backed with some powerful Pentecostal 'prophetic prayers' from her pastor. The promise of marriage was the primary motivation for the journey. Marriage is a source of glory to Africa's young and if the spouse lives abroad, that is itself 
considered an additional blessing from God. So in African Pentecostal breakthrough prayers, international travel is coveted as a sign of the workings of the prosperity gospel. Magda was three months away from delivery when her husband lost her job. Having lost the job, a process that was underway for his employers to get him proper documentation also collapsed. Within a week, a pregnant bride and her so-perceived God-given groom were illegal aliens in the USA. At that time, because Magda had also overstayed her visa, frustration set in for both of them.

The tensions arising from this difficult situation led to a divorce. On delivery, Magda weaned her twins prematurely and sent them to her family in Ghana. She stayed on in America. When I met her, she looked very troubled. Her savings of $\$ 10,000$ for a 'contract marriage' to enable her regularize her stay as an American citizen had been paid to a 'marriage contractor' who ran away with the money. Magda knew her action was wrong but her situation meant the only way to survive, was to engage in a false marriage by paying for it. She could not seek justice, as she was an illegal alien paying money for an illegal marriage. Magda still lives in the USA. She cries every day, even becoming hysteri$\mathrm{cal}$, and this for three interrelated reasons. First, being illegal in the USA means most things are done under a false identity. This is something she struggles to live with as a Pentecostal Christian. Second, she needs proper documentation to do most things and the attempt to enter into a contract marriage was supposed to help correct this position. Third, she misses her twin girls in Ghana but cannot travel to see them. My counsel for her to return home was not taken kindly: 'I left a good job in Ghana for a better life in America; my marriage has collapsed; and I have nothing to show for living here [in the USA] for so long; I feel like a failure I will not return for my enemies in Ghana to laugh at me. God will make a way for me.'

\section{$4 \quad$ Misfortune and Causality in Immigration Discourse}

Magda was certain - as with many African immigrants with documentation, employment, medical care and family life issues - that the cause of her problems is spiritual. She is convinced that her problems have arisen through a diabolical collaboration between witches in her family and the devil to thwart God's plans of prosperity for her life. This causal explanation pointing to the demonic as the source of misfortune does not allow for enough introspection. It accounts in part for the role that Pentecostal-type prayers in particular play in the process of migration and in the lives of immigrants. 'Forces', as evil powers are euphemistically referred to in Ghanaian public discourse, are there 
to frustrate God's plan for lives such as those of Magda. That immigrants use unethical and illegal means to regularize their stay abroad or work under false identities does not usually matter in African migration ethics. I have heard some in a similar position as Magda quote the following text as a form of assurance that things would eventually work:

When seventy years are completed for Babylon, I will come to you and fulfil my gracious promise to bring you back to this place. For I know the plans I have for you,' declares the Lord, 'plans to prosper you and not to harm you, plans to give you hope and a future. Then you will call upon me and come and pray to me, and I will listen to you (Jeremiah 29:10-12).

'Babylon' is the term for all the structures and institutions making it impossible for immigrants in the diaspora to succeed and powerful prayers are the means to deal with those obstacles.

There is no questioning the fact that African immigrant Christianity has helped in the transformation of the faith in the modern West. In reconstituting new believing communities outside of existing European churches and denominations, African immigrant churches make the presence of Christ felt in contexts that have all but lost a sense of Christian belonging and the workings of supernatural power. There is now enough academic research on mission and migration that demonstrates how immigrant churches have served to reverse in their own way the declining presence of Christianity in the Northern continents (Ludwig and Asamoah-Gyadu 2011; Hanciles 2008). What scholars of Christian mission and migration have not done is to reflect on the ethical issues arising out of migration activities in the search for proper documentation and employment. The new African immigrant churches are not all Pentecostal but have certainly been influenced especially by the prayer and prosperity culture of the movement. Pentecostal spirituality is orientated towards power encounter and discourses that sustain the worldview in which evil is hyperactive in human affairs and endeavours.

Thus we will consider African Christian migration within the context of the prosperity message associated with contemporary Pentecostalism. The ability of this type of spirituality to create Christianized ritual contexts of power for dealing with immigration issues has contributed to making it the religion of choice for many immigrants. The numbers of publications and conferences on 
non-Western immigrant Christianity are indicative of the importance of diaspora as a significant factor in Christian mission (Kim and Ma 2011). Diaspora practices and discourses however, throw up certain challenges that lead to innovative but unethical risky choices in the search for survival. In contemporary Pentecostal discourses the developed countries are the new 'promised lands' for desperate Africans in search of material fortune. Much prayer goes into these endeavours because the churches and their leaders are aware of the dangers of stranger-hood in fortress Europe.

Rijk van Dijk has noted that the present socio-political context of the modern state is that the stranger remains a perpetual stranger-a person who constantly disturbs the smooth evenness of our familiar social and cultural landscape by a persistent incongruity in it (Van Dijk 1997: 136). The implications of this determines the very unorthodox choices that the stranger has to make to ensure survival. For as Van Dijk further explains:

To the modern nation state the 'stranger' is a threat, a category that calls into question, and escapes from, established schemes, social grids and routines, and upsets the tranquillity of social arrangements and formations by becoming potential alternative (Van Dijk 1997: 136).

So far works on immigrant Christianity and mission have been based on the dynamism of the churches as important indicators of the health of African Christianity beyond the continent. Many of the churches are doing well and providing vibrant Christian worship communities for spiritually starving immigrants looking to express their faith in a living God. There is also the witness of presence. Through their dynamic and forceful churches, African Christians make the important theological statement that the Gospel of Christ is alive and well through those from the underside of history. The question is how strong can the testimony of a Christian be when he or she receives working papers through the assumption of false identities and contracting of false marriages? Prayers for documentation, employment and family related issues such as marriage and the desire to be able to bring spouses and children over, constitute three of the most important topics that dominate prayer in any African immigrant church in the developed West. That many of these prayers are supposedly 'answered' through the use of unapproved routes to travel or obtain documentation does not feature in the discourse. The tightening of immigration rules means that many immigrants have their backs to the wall and God has become the only source of hope and breakthrough against the fortresses of 'Babylon'. In other words, God is supposed to look at the situation and not the means through which these prayers may be fulfilled. 


\section{Migration and the Instrumentalization of Religion}

Many African immigrant churches are doing well, but we should not overlook the fact that they are also filled with desperate Africans looking for a way out of the quagmire of living abroad without proper documentation. The lack of proper documentation means that access to health care in a lot of countries, employment, and the ability to reunite with family or attend to important family matters such as funerals of parents are all impossible. The alienating conditions of illegal migration can be traumatic and depressing. Returning home to Africa is just not an option because it complicates matters. Many immigrants, especially professionals have woken up to the realization that the colleagues they left in Ghana for example, have moved on and achieved far more in terms of material acquisitions and family stability than they have done abroad after years of sojourning there. As one immigrant said during a conversation: 'We want to return home, yes, but going home is not the issue. It is the how.'-'How' in this context does not necessarily refer to the airfare but rather what this individual, as with the case of Magda, has to show for years of living abroad.

To that end, Ebenezer Obadare and Wale Adebanwi have pointed to an important vacuum in the literature on religious transnationalism by highlighting how would-be migrants turn to and instrumentalize religion in the processes of migration (Obadare and Adebanwi 2010: 31-48). They discuss how potential immigrants resort to various 'traditional' or even 'juju' rites as 'part of a complex repertoire of spiritual and other resources' by drawing on them to achieve their immediate goal of evacuating their countries (Obadare and Adebanwi 2010:33). In terms of academic study, the instrumentalization of religion serves as important primary material for social anthropologists who study religion and migration in relation to Africa. Mission studies, unfortunately, has tended to romanticize African immigrant Christians for working to restore the fortunes of the faith in the West without attention to immigrant pastoral problems and ethical issues that undermine Christian ethics and witness.

The difficulty in international travel arrangements make it such that for a people with a supernatural orientation to life, religion becomes an important instrument in migration. Resorting to the services of shrine priests, and Christian pastors and prophets are options in the process of deactivating activities of witches - mostly suspected to be envious relations - employing witchcraft or 'African electronics', as it is popularly called, against one's progress and activate the power of God for things to happen. At 'prophetic prayer meetings' in urban Africa potential immigrants call upon the fire of God to deal ruthlessly with relations spiritually impeding their travel plans. Struggling immigrants 
also fire spiritual missiles back to Africa to decimate the lives of family witches working against them. In the process Old Testament imprecatory prayers have been incorporated into spirituality without any sense of Christological critique of these vengeance prayers.

For many potential migrants, as Obadare and Adebanwi note, the primary concern is a religious resource that works - whether Christian, traditional or Muslim. There is a greater concern, they note, 'with which religious authority is putatively acclaimed to guarantee success with the visa process at any particular time, rather than his or her denominational identity' (Obadare and Adebanwi 2010: 34). In 2001, a British High Commission official expressed consternation on Joy FM radio regarding reports that potential Ghanaian immigrants often take the names of officials in his outfit to shrines and Spiritual churches. They go there in search of 'supernatural assistance' to bend the minds of officials so that requests for travel documentation would be granted. At the popular Pentecostal prayer camp at Edumfa in the Central Region of Ghana, heaps of passport belonging to potential migrants sit on a table in front of the prophetess in charge at every prayer service as she invokes the blessing of God upon the owners for divine breakthrough at embassies as they apply for travel documentation and visas.

This is not just a traditional religious or occult problem. It has become a pastoral problem too because the need for supernatural intervention has generated a crop of Christian charismatic pastors whose specialties lie in prayers of supernatural breakthrough for visas and employment in the diaspora. As with the traditional settings, it is not uncommon for Christian pastors to request potential migrants and immigrants to sow a 'seed', that is, remit money to Africa as ritual for sustaining whatever breakthroughs they may be enjoying as a result of prayer offered on their behalf. You sow a seed to open doors and you have to continue to sow those seeds to keep the doors of breakthrough open. The fact that some of the problems for which people are seeking supernatural interventions are self-inflicted through lies does not usually feature in the discussions. It is a common experience to find potential immigrants in churches of Pentecostal persuasion because their focus on supernatural intervention feed into the needs and discourses of migration. God, as Obadare and Adebanwi note, is thus very much a 'visa' and 'documentation' God as the following prayer indicates: 
Loving Lord! The Scripture say You are aware of all our needs, even before we ask You. So I come to You and place this request at Your loving hands. You know how desperate I am for getting the Visa. My soul has become weary and anxious over this delay in getting the visa. O Lord! Speak in the hearts of the concerned officials, grant me favour in their eyes and help me to get my visa on time so that my purpose is fulfilled. Perfect everything for me my Master. I wait at your feet and trust in you to make this possible. I know that You will do it, for You will never let Your children down. I thank You for listening to my plea! To You alone be all honour and glory. In the sweet name of Jesus I pray. Amen (Obadare and Adebanwi 2010: 38).

Rijk van Dijk also reports from a Church of Pentecost prayer camp in Accra that those admitted for reasons of international travel had been increasing (Van Dijk 1997: 145). They go to the camps for prayer against witches of the African universe, mainly envious relations who unrestrained by distance are able to undo plans and bring victims to ruin. If proper protection is not sought, witches can thwart physical plans by working against the issuance of visas or instigating the repatriation of those already living abroad. Van Dijk explains how concerned family members get involved in the religious aspects of migration:

Once a migrant has made it to Europe, close relatives might occasionally come and stay at the prayer camps to engage in prayer for the success and protection of the one who has travelled abroad. This practice is closely linked to the notion of social investment that a family makes in one of its younger members to allow him to travel to the West to send home revenues. It is thus considered a deep family crisis whenever such a family member sends no money or other signs of their well-being. Such a crisis might again prompt family members to stay at a prayer camp to mollify the heavenly powers that they may change the spirit of the migrant or cast out the demon that is blocking the flow of substances sent home (Van Dijk 1997: 145).

That the popular expression in Ghana for witchcraft activities is 'African electronics' says much about what people believe about these 'forces' of harm and why migration plans tend to be some of the best kept secrets from relations in Africa. In one church a young man who had received his breakthrough by obtaining a five-year multiple entry visa to the USA brought his passport to church. The pastor then took the passport, opened to the page with the visa 
stamp and went from row to row showing what God could do for those who come to that particular church seeking supernatural intervention. There were no questions asked regarding the obvious fact that this individual does not intend to return to Ghana after visiting the USA. The reasons for travel and what awaited this young man abroad were not important here. What was important was that he had obtained a visa to travel to the USA and this was divine breakthrough into success and prosperity of the material kind. The interest of the pastor goes beyond the workings of his prayerful interventions because of the 'seeds' of money and gifts that the immigrant sends in gratitude for those powerful prayers that make travel possible (Van Dijk 1997: 145).

\section{Precarious Diasporas and Situation Ethics}

At this point I recount two other major incidents that occurred in the lives of immigrant communities in Europe and the USA that are relevant to our discussion in terms of migration stories with implications for Christian ethics and morality. In the first incident a member of a Ghanaian immigrant Christian community died suddenly in his sleep one night. The death was discovered on a Sunday morning when the landlady who was a member of the church the deceased used to attend, tried to call him that it was time to go to church. When the lifeless body was discovered, the landlady knew she was in trouble with the law. It is against immigration law in the Netherlands to accommodate an undocumented immigrant but the lady had placed 'Christian love' above state law and now she had to answer to the authorities for a 'Samaritan' act that had gone horribly wrong. Eventually the Christian church where they both worshipped stepped in, took responsibility for the burial and the police decided that since the gentleman died of natural causes and the state was not going to incur debts, charges against the young lady were to be dropped.

The second incident was when while visiting the USA, I had to fill some forms and needed an endorsement from a friend who had lived there for many years. Knowing his name, I had actually filled out the form and taken it to him for signature. That was when I learnt that the name in his passport was different from what I knew him to be called. As he explained to me later, the situation demanded a change of name: 'On my first entry into the country, I overstayed and was repatriated. On the second attempt, I had to change my name, age and passport in order to avoid being found out that I was the same person.' There are numbers of Africans who live abroad under false identities. The circumstances under which people assume these false identities differ but in many cases, they are either the identities of deceased friends and relatives or they are 
acquired through false or 'contract' marriages. As Van Dijk explains marriage is an important 'entry ticket' for many migrant groups into the Dutch welfare system and has since the 1980 s acquired 'a highly contested significance in the context of Dutch immigration and identity policies' (Van Dijk 2004: 451).

\section{Resident Aliens: Patriarchal Narratives in Immigration Experiences}

In the circumstances described so far, the story of Abraham and Sarah in Egypt has often been quoted in support of decisions that in principle may weigh against Christian ethics. Claudia Währisch-Oblau explains that African immigrant Christians in Europe 'pray for changed government policies and even confront the 'demon of racism' in their spiritual warfare' (Währisch-Oblau 20og: 31 ). At these intensively emotional and physically aggressive prevailing prayer services the name and authority of Jesus or the power of God are forcefully invoked to deal with those representing 'Babylon' and making international travel difficult. That the word 'alien' is the official designation for immigrants in many Western countries already introduces a religious dimension into migration discourses in the imagination of African Christians.

In their position as aliens, the Israelites came up against much in terms of hard labour, oppression and denial of basic rights but God was always at hand to intervene on behalf of his people. In Deuteronomy 26, members of the Israelite worshipping community present a basket of the 'first and the best' of their produce in gratitude for God's deliverance for their alien forefathers in Egypt. The presentation begins with the liturgical chant that recounts the historical and momentous deliverance as passed down to later generations:

My father was a wandering Aramean, and he went down into Egypt with a few people and lived there and became a great nation, powerful and numerous. But the Egyptians mistreated us and made us suffer, putting us to hard labor. Then we cried out to the Lord, the God of our fathers, and the Lord heard our voice and saw our misery, toil and oppression... and now I bring the first-fruits of the soil that you O Lord have given me... (Deut. 26:5-10).

What is important from the viewpoint of the immigrant is the presentation of God here as the God of deliverance from the forces of oppression and who deserves the 'first and best' in gratitude. Thus, an important means of sustaining God's blessing is to be faithful in the payment of tithes and offerings often directly to the 'man of God' or 'woman of God' whose prayerful interventions 
are credited for migration success and prosperity. The 'average' African immigrant Christian identifies with these Biblical experiences and that explains in part the strong relationship that exists between religion and migration in African immigrant discourse. Biblical passages that talk about God's interventions on behalf of the alienated and oppressed thus resonate very much with the hopes and aspiration of African immigrant Christians and they are reinvented and applied in contemporary discourses and prayers.

In short, living in the diaspora, especially as an undocumented alien, can be a precarious endeavour and strategies of survival usually break the limits of Christian ethics. 'Our position is not new,' one Ghanaian illegal immigrant noted, 'even Abraham was an illegal alien in Egypt and because God was on his side, he succeeded.' The Biblical narrative from which my friend was making his case for continued stay abroad without proper documentation reads as follows:

Now there was a famine in the land, and Abram went down to Egypt to live there for a while because the famine was severe. As he was about to enter Egypt, he said to his wife Sarai, "I know what a beautiful woman you are. When the Egyptians see you, they will say, 'This is his wife.' Then they will kill me but will let you live. Say you are my sister, so that I will be treated well for your sake and my life will spared because of you" (Genesis 12:10-13).

The 'famine' in Egypt is used here as a symbolic representation of all the socioeconomic and political reasons why people migrate from Africa to North America and Europe. Now economies have started improving but for many years even African professionals like doctors and nurses were better off undertaking menial jobs abroad than work within their professions in Africa. For many ordinary African school leavers - no matter the level — their best option of making it in life in terms of economic prosperity is still migrating to any of the Western countries and slugging it out in those harsh conditions to eke out a living and extend an economic lifeline to brothers, sisters, nieces, nephews and parents and parents in law back in Africa.

Jacob is also reinvented in contemporary Pentecostal preaching, not as a cheat but as one in whose life God's purposes were fulfilled through taking advantage of situations in which he found himself. In using the tales of the lives of Jacob and Esau in charismatic preaching, the emphasis shifts from what grace and mercy can accomplish with the worst of sinners and truants, to

1 Conversations with an undocumented migrant in Maryland, USA in May 2012. 
reinterpreting Jacob's exploitative approach to life as wisdom principles that culminate in prosperity and success. I am not suggesting that those preaching this way recommend illegal migration but the reinterpretations of the life of Jacob when stretched to its logical limits virtually supports the position that the end justifies the means!

The contemporary charismatic interpretation is that life is about smart negotiations. This is illustrated by the picture of a handshake involving a black hand and a white one on the cover of Mensa Otabil's book Buy the Future which brings together a series of sermons on Jacob. In Quest for Supremacy, by Eastwood Anaba, life is about 'wrestling' for your place and this is illustrated by the two wrestlers in combat on the front cover of Anaba's book. Thus against the grain of conventional understanding of Jacob as a sinner transformed by grace from a 'supplanter' to Israel, he is presented by the two contemporary Pentecostals as one who made right and perceptive choices with the 'future' and 'supremacy' in mind. This is how Otabil interprets Jacob:

Most people see him as a trickster and a fraud who exploited his brother Esau.... Jacob did not spend his time scheming to take advantage of people. He developed a character that was very different from his name; he was an upright man. Later on in life, after a season of struggle for divine blessing, God rightly changed the name of Jacob to reflect his true heritage (Otabil 2002: 28).

Anaba takes a similar position that Jacob was not a cheat he simply had business sense when he notes that:

Jacob was not a dishonest person who subverted his brother, Esau's position, to take away his birthright. As good men and women struggle to come out of the rubble of life it is not unusual to see them dented and distorted by the pressures around them; God concentrates on the good underneath the dents but man fixes his gaze on the dents (Anaba 2004: vi-vii).

The references to 'struggles' in Otabil and to 'dents' in Anaba are important because it shows that charismatic pastors such as the two we examine do not take a simplistic approach to prosperity. The road to our God-given destinies has many obstacles but they are only transient if one stays focused and works towards those goals in search of a better future or supremacy. Thus as Anaba explains: 'God turns the obstacle into a springboard to catapult you to another level of supremacy. Obstacles are not meant to obstruct you but to uplift you' (Anaba 2004: 32). 
In this matter, the Biblical Abraham tends to be an important paradigm not simply as a model of faith but also in negotiating one's way out of danger in spite of the ethical demands of faith. In the contemporary application of the Abrahamic strategy, telling lies and falsifying documents may well be God's way of helping his children realize their divine destinies. Migration as we see from the story of Abraham, especially in his initial journey into Egypt is accompanied by its own challenges. Our focus here has been on some of these challenges in the lives of Christian immigrants in Africa and the struggle to live by Christian ideals in contexts where many Christians have had to lie or assume false identities in the search for survival.

We live today in what Walls describes as 'a post-Christian West and a postWestern Christianity' (Walls 2002: 3-4). He notes that, in relation to this development that 'Christianity will now increasingly be associated (mostly) with rather poor and very poor people, and with some of the poorest countries on earth' (Walls 2002: 10). People migrate in search of better conditions of living and as they do so, it has been established, they go with their faith. Adogame points out that next to the intentional expansion of mission, migration is the most important factor determining the spread of religion. An important part of the process is what he calls 'chain migration' in which spouses and families migrate to join the first comers (Adogame 2013: 10). Even when they were not originally confessing Christians, a lot of immigrants have come to faith through the difficulties of living in foreign lands and here, they begin to call on God for deliverance from security authorities doing the legitimate work.

Andrew Walls concludes on the presence of non-Western Christians in a lot of Western countries that, 'Christianity will be associated increasingly with immigrants' (Walls 2002: 10). It is the quest for the preservation of faith that sometimes conflicts with the strategies of survival leading to the deployment of situation ethics. In the Biblical record Abram, later to become the father of faith, was driven to move as a result of hunger in his homeland and once in Egypt following this migration, he found himself having to lie about his relationship with Sarai in order to survive (Gen. 12). That is what is also revealed in the Biblical records where the pains of exile also became opportunities for seeking divine intervention and keeping the messianic hope alive. In the case of Israel they continued to receive prophetic assurances that some 
divine purpose was being worked out within the pains of exile. Of the many Old Testament promises of divine intervention that today's African Christian immigrants identify with, one of the most favoured is Jeremiah 29:11-12,

For I know the plans I have for you, declares the Lord, "plans to prosper you and not to harm you, plans to give you hope and a future. Then you will call upon me and come and pray to me, and I will listen to you".

When this promise is invoked in African immigrant churches today, it is not necessarily interpreted to mean that God is going to take his people back to Africa from exile. The modern interpretations relate to God's promises and plans of prosperity as people hold on to the hope of faith in those places where they now live in search of better fortunes in life. The Abrahamic incident occurs between the period of promise and consummation of the covenant made between God and Abram. In African Christianity today, the Pharaohs who put the lives of the people of God in danger may be the embassy official, the immigration officer, the policeman or woman and people of such standing who in the course of their official duties make it difficult for the potential migrant to travel or the immigrant to live and work in a foreign land. The fact that the stranger experiences disciplinary actions taken by the host nation state as it attempts to intervene in diasporic flows has led to the development of shared strategies of survival among immigrants. These strategies of survival, we have noted, include the assumption of false identities, claiming forced asylums and entering into illegal unions in order to beat the systems in place.

The Pentecostal/charismatic discourses of power and supernatural intervention enable the creation of the appropriate ritual contexts for dealing with the challenges of being aliens in foreign lands. In the wake of the increasing numbers of non-Western immigrant churches in the diaspora, studies point out that it is the turn of the churches in the Global South to revive the Western church. This makes the role of the diaspora in the secular West critically important. Yet the challenges of being an alien require unorthodox strategies of survival that may undermine Christian ethics and pitch immigrants against the laws of host countries. The materialistic orientation of the gospel of prosperity in contemporary Pentecostalism means that international travel has gained high priority as the focus of preaching, teaching, prophetic declarations, the lyrics of gospel music and prayer. The opportunity to travel and what goes into it are not as straightforward as one may think. 
Religion is important not simply as a means of identity but the processes of travel and access to social and economic services may involve risky undertakings for which religion is needed as a means of response. The processes involve filling physical forms and also dealing with human beings who are doing their work, but supernatural forces, working through the physical forces can interfere negatively with these arrangements. To counter their effects powerful prayers are required. Thus obtaining resident papers, employment or the ability to bring spouses and relations over are major thanksgiving occasions in African immigrant churches. For those whose arrangements to travel were aided by traditional religious functionaries and diviners, appropriate tokens are duly sent to the countries of origin in fulfilment of pledges made. In both the Christian and traditional religious settings, it is believed, the reneging on such responsibility could lead to the derailment of plans abroad. The evils that occur in the lives of migrant are often interpreted in Biblical terms as the release of 'pests' by the Lord to devour the fortunes of those holding back what is due him (Malachi 3:11).

In contemporary Pentecostal discourse, foreign lands are now linked to personal destinies in virtually the same way that the destiny of Israel was linked to the promise land. One of the first motifs that we encounter in the very first book of the Bible is the divine promise to the Patriarchs, in which the promise of land is a major element (Frankel 2011: 2). In Exodus through Deuteronomy, the goal and purpose of the exodus from Egypt are depicted in terms of fulfilling the promise to provide Israel with a land 'flowing with milk and honey' (Ex. 3:8; Deut. 7:23). The book of Deuteronomy continues to accentuate the issue of the land, its conquest and settlement, bringing the theme to an even higher level of prominence. The land is continually referred to in Deuteronomy as the ultimate gracious gift that the Lord bestows upon the people of Israel (Frankel 2011:4).

It is from the land that people eke out a living and it is on it they settle and that means human destiny is itself based on the availability of land. Thus the promise of land to the Patriarchs has become metaphorical for human aspirations which are linked with divine promise. This explains why certain Old Testament narratives possess such a unique appeal for contemporary Pentecostal preachers who encourage members to pursue their material aspirations through such themes as: 'take territories', 'possess your possessions' or 'occupy the land'. The land may be interpreted as a land of promise but it is also understood that to be an alien in a foreign land, comes with specific problems:

1. The land devours aliens because of the giants who live there (Spying the Land). 
2. Survival in exile may sometimes require that one is economical with the truth (Abram and Sarai).

3. Related to point 2 is the fact that being an immigrant may require a different set of ethical rules.

The problems of the 'average' African migrant usually depend on a number of factors including social status, employment situation, immigrant status, linguistic ability, and the like. The influence of pneumatic ministries that spiritualize problems and promise supernatural interventions because of prayers from 'powerful' charismatic pastors means that the types of Christian spirituality on offer feed and encourage traditional beliefs on mystical causality. Prayers are often 'supernatural scud missiles' sent over the seas to destroy those responsible for the lack of success abroad. Stories of witchcraft abound among Ghanaians about how envious relations assisted by the powers of witchcraft have appeared in dreams abroad pursuing their victims in order to make their lives miserable.

\section{Conclusion}

There are no easy answers to the questions raised here and in my experience even the most honest and spiritual of African pastors has to contend with members who are undocumented in the congregation. Many pastors have to make a choice regarding the ethical propriety of allowing notices regarding the availability of documents for the undocumented to secure work when it goes both against the laws of the host country and Christian ethics. Whatever it is immigrant Christianity serves an important purpose in mission to the Northern continents. Nevertheless, we must also confront the issue of the provision of pastoral care to people who are surviving by flouting immigration laws of host countries and demonizing others for the problems that this generates for their lives abroad.

\section{Bibliography}

Adogame, Afe (2013). The African Christian Diaspora: New Currents and Emerging Trends in World Christianity. London: Bloomsbury. Anaba, Eastwood (2004). The Quest for Supremacy. Accra: Design Solutions.

Asamoah-Gyadu, J. Kwabena (2013). Contemporary Pentecostal Christianity: Interpretations from an African Context. Oxford: Regnum International.

Barclay, William (1971). Ethics in a Permissive Society. London and Glasgow: Fontana. 
Dijk, Rijk A. van (1997). "From Camp to Encompassment: Discourses of Transsubjectivity in the Ghanaian Pentecostal Diaspora." Journal of Religion in Africa 27, 2: $135^{-159 .}$

Dijk, Rijk A. van (2004). "Negotiating Marriage: Questions of Morality and Legitimacy in the Ghanaian Pentecostal Diaspora." Journal of Religion in Africa 34, 4: 438-467.

Fletcher, Joseph (1966). Situation Ethics. London: Scm.

Frankel, David (2011). The Land of Canaan and Destiny of Israel: Theologies of Territory in the Hebrew Bible. Winona Lake In: Eisenbrauns.

Hanciles, Jehu (2008). Beyond Christendom: Globalization, African Migration and the Transformation of the West. Maryknoll NY: Orbis Books.

Kim, S. Hun and Wonsuk Ma, eds. (2011). Korean Diaspora and Christian Mission. Oxford: Regnum.

Levitt, Peggy (2007). God Needs no Passport: Immigrants and the Changing Religious Landscape. New York: The New Press.

Ludwig, Friedrich and J. Kwabena Asamoah-Gyadu, eds. (2011). African Christian Presence in the West. Trenton NJ: Africa World Press.

Obadare, Ebenezer and Wale Adebanwi (2001). "The Visa God: Would-be Migrants and the Instrumentalization of Religion." In Afe Adogame and James V. Spickard, eds. Religion Crossing Boundaries: Transnational Religious and Social Dynamics in Africa and the New African Diaspora. Leiden: Brill: 31-48.

Otabil, Mensah (2002). Buy the Future: Learning to Negotiate for a Better Future than your Present. Accra: Altar Media.

Währisch-Oblau, Claudia (2009). The Missionary Self-Perception of Pentecostal/ Charismatic Church Leaders from the Global South in Europe: Bringing Back the Gospel. Leiden: Brill.

Walls, Andrew F. (2002). "Mission and Migration. The Diaspora Factor in Christian History." Journal of African Christian Thought 5, 2: 3-11. 